Nearfield Unsteady Pressures at Cruise Mach Numbers for a Model Scale Counter-Rotation Open Rotor

David B. Stephens

Glenn Research Center, Cleveland, Ohio 


\section{NASA STI Program . . . in Profile}

Since its founding, NASA has been dedicated to the advancement of aeronautics and space science. The NASA Scientific and Technical Information (STI) program plays a key part in helping NASA maintain this important role.

The NASA STI Program operates under the auspices of the Agency Chief Information Officer. It collects, organizes, provides for archiving, and disseminates NASA's STI. The NASA STI program provides access to the NASA Aeronautics and Space Database and its public interface, the NASA Technical Reports Server, thus providing one of the largest collections of aeronautical and space science STI in the world. Results are published in both non-NASA channels and by NASA in the NASA STI Report Series, which includes the following report types:

- TECHNICAL PUBLICATION. Reports of completed research or a major significant phase of research that present the results of NASA programs and include extensive data or theoretical analysis. Includes compilations of significant scientific and technical data and information deemed to be of continuing reference value. NASA counterpart of peer-reviewed formal professional papers but has less stringent limitations on manuscript length and extent of graphic presentations.

- TECHNICAL MEMORANDUM. Scientific and technical findings that are preliminary or of specialized interest, e.g., quick release reports, working papers, and bibliographies that contain minimal annotation. Does not contain extensive analysis.

- CONTRACTOR REPORT. Scientific and technical findings by NASA-sponsored contractors and grantees.
- CONFERENCE PUBLICATION. Collected papers from scientific and technical conferences, symposia, seminars, or other meetings sponsored or cosponsored by NASA.

- SPECIAL PUBLICATION. Scientific, technical, or historical information from NASA programs, projects, and missions, often concerned with subjects having substantial public interest.

- TECHNICAL TRANSLATION. Englishlanguage translations of foreign scientific and technical material pertinent to NASA's mission.

Specialized services also include creating custom thesauri, building customized databases, organizing and publishing research results.

For more information about the NASA STI program, see the following:

- Access the NASA STI program home page at http://www.sti.nasa.gov

- E-mail your question to help@sti.nasa.gov

- Fax your question to the NASA STI Information Desk at 443-757-5803

- Phone the NASA STI Information Desk at 443-757-5802

- Write to: STI Information Desk NASA Center for AeroSpace Information 7115 Standard Drive Hanover, MD 21076-1320 
NASA/TM-2012-217672

Nearfield Unsteady Pressures at Cruise Mach Numbers for a Model Scale Counter-Rotation Open Rotor

David B. Stephens

Glenn Research Center, Cleveland, Ohio

Prepared for the

18th Aeroacoustics Conference

cosponsored by the American Institute of Aeronautics and Astronautics and Confederation of European Aerospace Societies

Colorado Springs, Colorado, June 4-6, 2012

National Aeronautics and

Space Administration

Glenn Research Center

Cleveland, Ohio 44135 


\section{Acknowledgments}

This report was funded by the NASA Environmentally Responsible Aviation (ERA) project and the NASA Subsonic Fixed Wing (SFW) project.

Level of Review: This material has been technically reviewed by technical management.

Available from

NASA Center for Aerospace Information 7115 Standard Drive

Hanover, MD 21076-1320
National Technical Information Service 5301 Shawnee Road Alexandria, VA 22312

Available electronically at http://www.sti.nasa.gov 


\title{
Nearfield Unsteady Pressures at Cruise Mach Numbers for a Model Scale Counter-Rotation Open Rotor
}

\author{
David B. Stephens \\ National Aeronautics and Space Administration \\ Glenn Research Center \\ Cleveland, Ohio 44135
}

\begin{abstract}
An open rotor experiment was conducted at cruise Mach numbers and the unsteady pressure in the nearfield was measured. The system included extensive performance measurements, which can help provide insight into the noise generating mechanisms in the absence of flow measurements. A set of data acquired at a constant blade pitch angle but various rotor speeds was examined. The tone levels generated by the front and rear rotor were found to be nearly equal when the thrust was evenly balanced between rotors.
\end{abstract}

\section{Nomenclature}

$f \quad$ Frequency, $\mathrm{Hz}$

$B \quad$ Number of rotor blades

$c \quad$ Speed of sound, $\mathrm{m} / \mathrm{s}$

$D \quad$ Rotor diameter, $\mathrm{m}$

$J \quad$ Rotor advance ratio, $V_{0} / N \pi D$

$M \quad$ Mach number, $V / c$

$m \quad$ Front rotor blade rate harmonic number

$N \quad$ Rotor shaft rotation frequency, $\mathrm{Hz}$

$n \quad$ Aft rotor blade rate harmonic number

SO Shaft Order, $f / N$

$T$ Thrust, $\mathrm{N}$

$Q$ Torque, $\mathrm{Nm}$

$V \quad$ Velocity, $\mathrm{m} / \mathrm{s}$

$\eta \quad$ Propeller efficiency, $T V_{0} / Q N$

$\theta \quad$ Sideline angle measured from upstream along the model centerline

\section{Introduction}

The nearfield unsteady pressure field near a model scale open rotor was evaluated in the 8x6 Supersonic Wind Tunnel at NASA Glenn Research Center (GRC). High-speed propellers and open rotors offer considerable fuel efficiency benefits compared with turbofans, but these systems present noise challenges to both the community around the airport and to persons on the airplane. A recent test campaign was conducted as a collaboration between NASA and General Electric Aviation (GE) to document the performance and acoustics of open rotors. Advanced blade designs have been developed by GE since the previous test campaign in the 1980's. The primary incentive for implementing open rotor propulsion is the fuel efficiency at cruise Mach numbers, and this tunnel was operated between Mach 0.27 and Mach 0.85. During the test, a streamwise 
line array of unsteady pressure transducers was mounted to a plate above the model which could be lowered from the tunnel ceiling toward the blade tip. These data could be used for estimating structural loading on the airframe or for estimating en route noise, for example.

Open rotors were previously studied in the 8x6 Supersonic Wind Tunnel during the mid 1980's. The results from those tests were documented in a number of reports including those by Dittmar [1], Dittmar and Stang[2, Dittmar et al. [3] 2] and Whitfield et al.4].

\section{Experiment}

The tests described in this report were conducted in the 8x6 wind tunnel from February to September 2011. As described below, these tests included scaled aerodynamic performance, structurally responsive blades, and realistic acoustic signatures. Comparisons of model scale acoustic data to the full-scale counter rotating engine flight test in the 1980's were found to be in good agreement. [5]

\subsection{Drive Rig}

The NASA counter rotating open rotor propulsion rig (ORPR) was used to power the open rotor blades in this experiment. The rig consists of two counter rotating spools with a non-rotating center shaft. Each of the two counter rotating spools is attached to a two-stage air turbine on the aft end that can produce up to $560 \mathrm{~kW}(750 \mathrm{HP})$. The two air turbines are supplied by $2 \mathrm{MPa}(300 \mathrm{psi})$ air heated to $90^{\circ} \mathrm{C}\left(200^{\circ} \mathrm{F}\right)$, and can be independently controlled using a feed-back system to drive the rotor speeds independently to more than 8,000 RPM with an accuracy of \pm 15 RPM. This drive rig was operated in the late 1980's, and was refurbished in order to correct any detrimental effects of long-term storage. The refurbishment activity consisted of a general inspection and rebuild of the mechanical components, construction of a new swept pylon, refurbishment of the forward and aft rotating force balances and installation of a telemetry system. This rig was operated in a low-speed test campaign from late 2009 to late 2010 in the 9x15 Low Speed Wind Tunnel at NASA Glenn. Reports to data on data from the low speed portion of this project include Elliott [6] and Stephens and Envia 7 , and Berton 8 . The refurbished ORPR installed in

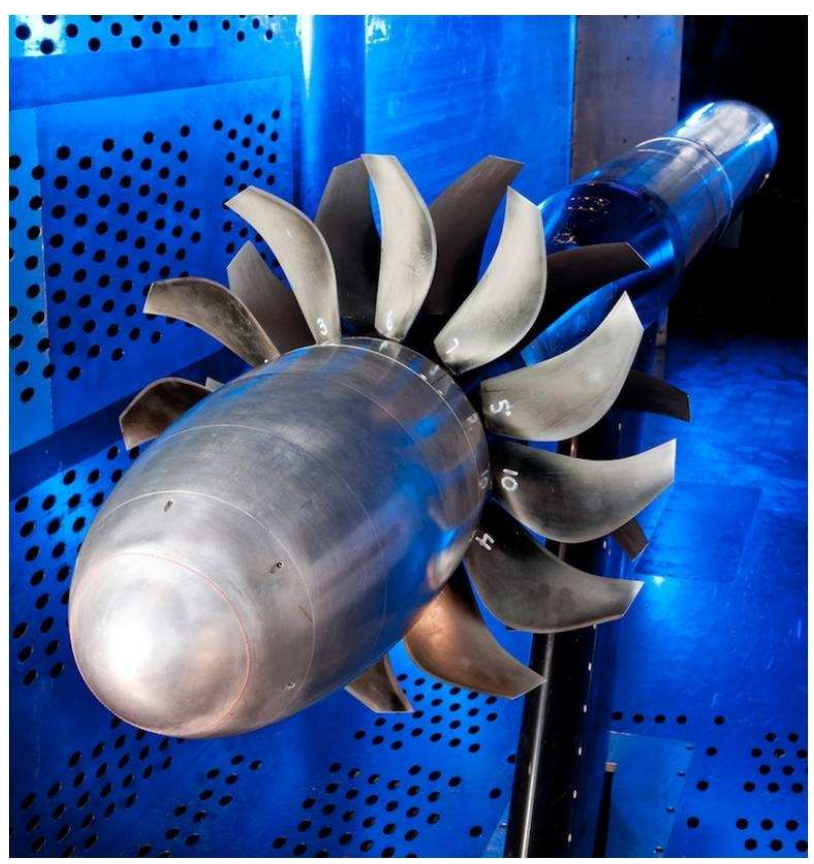

Figure 1: Open Rotor Propulsion Rig and F31/A31 blade set in 8x6 Wind Tunnel at NASA Glenn Research Center. NASA Image C-2010-3454. the $8 \times 6$ Wind Tunnel is shown in Figure 1 .

\subsection{Historical Baseline Blades (F31 / A31)}

The model test hardware simulates a counter rotating open rotor engine design. New hubs were manufactured as part of the current test campaign, with support for 12 blades for the forward rotor and 10 blades for the aft rotor. The pitch angle setting for both blade rows are manually adjustable. The blade set used for the tests described in the present paper was designed and manufactured by GE and is known as F31/A31. This blade set represents a good early 1990's aerodynamic design, but is not acoustically optimized. The F31/A31 blade set was manufactured with modern materials and techniques for this test, and will be used to provide a baseline to anchor new data. The forward rotor is $65.18 \mathrm{~cm}$ (25.66 inches) in diameter and the aft rotor is $62.97 \mathrm{~cm}$ (24.79 inches) in diameter. Axial spacing between the two rotors is variable, but was set at 19.91 $\mathrm{cm}$ (7.84 inches) between the pitch change axis of each rotor for the data presented in this report. The center 
of the aft rotor at the blade pitch change axis location is the origin of the coordinate system for the results shown in this paper, except where noted.

\section{$2.3 \quad 8 \times 6$ Wind Tunnel}

The $8 \times 6$ Wind Tunnel at GRC is a high speed wind tunnel with velocity capabilities from Mach 0.27 to Mach 2.0. The test section is $2.44 \mathrm{~m}$ high by $1.83 \mathrm{~m}$ wide ( 8 feet by 6 feet) and $7.16 \mathrm{~m}$ (23.5 feet) long. The test section has perforated bleed holes for boundary layer removal that are used when the tunnel is operated at transonic velocities. The flow is driven by three electric motors that can produce up to $65 \mathrm{MW}(87,000$ HP). A description of the $8 \times 6$ Wind Tunnel complex is given by Soeder 9 .

\subsection{Acoustic Instrumentation}

The unsteady pressure instrumentation was an aluminum plate with 17 flush-mounted XCS-093-15SG transducers made by Kulite Semiconductor. The transducers offer a 15 PSI range and are temperature compensated. The calibration values provided with the instrumentation were used to convert the voltage output to unsteady pressure. These sensors were connected to a Precision Filter and recorded by a RC Electronics DataMAX. The pressure transducers were simultaneously sampled at 200 $\mathrm{kHz}$ in 15 second long records. These records were processed into narrowband SPL using the Digital Acoustics Data Software (DADS) package developed at GRC. The instrumented plate could be remotely lowered from the tunnel ceiling to achieve various sideline distances from the model axis of rotation. A table of the geometry is in Table 1. These locations are relative to the location of the aft rotor pitch change axis. A schematic of the instrumentation relative to the model turboprop is shown in Figure 2.

\subsection{Operating Conditions}

An extensive range of operating conditions were tested, with blade pitch angles for the forward and aft blades ranging from $43.0^{\circ} / 43.5^{\circ}$ at Mach $0.27-0.45$ to $64.4^{\circ} / 61.8^{\circ}$ at Mach $0.73-0.85$. Powered rotation speeds ranged up to $8250 \mathrm{RPM}$. The thrust and torque of each rotor were measured by custom built rotating balances mounted in the hub of each rotor. Maximum thrust was limited by the instrumentation to $2 \mathrm{kN}$ (450 lbf) per rotor while torque was limited to $680 \mathrm{Nm}(500 \mathrm{ft}-\mathrm{lb})$ per rotor.

A large number of conditions were tested, with several hundred readings of data taken with the F31/A31 blade set. Most of these were taken with the Kulite plate in the stowed position against the test section ceiling, so are not particularly interesting for unsteady pressure measurements, due primarily to the limited directivity that could be measured in this configuration. At Mach 0.4 with the plate in the stowed position, the sensors only span emitted angles between 46 and 90 degrees. With the plate lowered to $0.78 D_{f}$ above the model centerline, at Mach 0.78 the directivity spans emitted angles of 12 to 97 degrees from upstream. The rest of the data presented in this report is from the model at these operating conditions.

A set of readings was chosen as representing a particularly interesting subset of the data. These readings represent a series of increasing rotor speeds at Mach 0.78 that include a local peak in the propulsive efficiency. The ORPR does not have a powered or automated mechanism for changing the rotor blade pitch during a run, so only a limited number of iterations on blade pitch was practical during the course of testing. Changes to the rotor RPM at a fixed tunnel velocity $V_{0}$ provide a substitute method for changing the blade inflow angles. A few performance metrics for these readings are given in Table 2 where the total thrust is given as a fraction of the maximum total rating for the thrust balances $(4 \mathrm{kN})$. Details of the performance calculations are given in the report by Hughes and Gazzaniga. [10] While it would be desirable from a scientific standpoint 


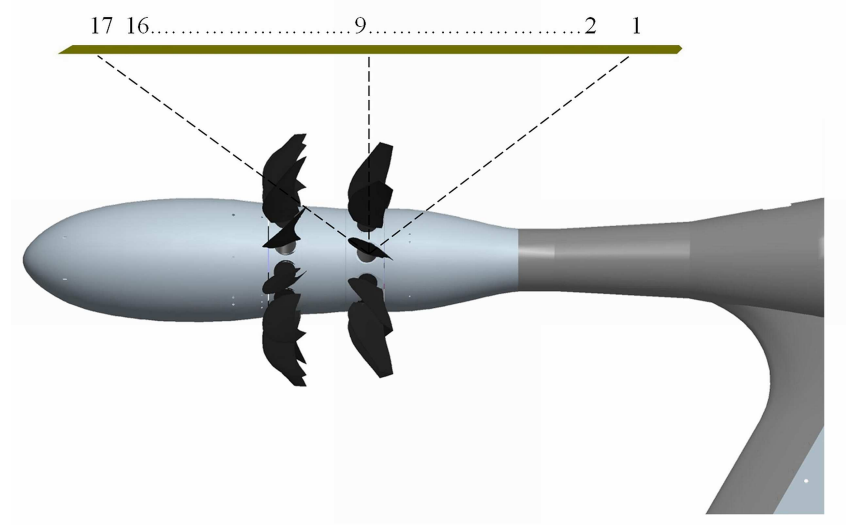

Figure 2: Illustration of the unsteady pressure instrumentation in the $8 \mathrm{x} 6$ wind tunnel. Plate is shown at the sideline distance of $0.78 D_{f}$. Measurement locations are numbered from downstream.

Table 2: Open Rotor Performance at Mach 0.78. $\beta_{f}=64.4, \beta_{a}=61.8, H_{\text {plate }}=0.78 D_{f}$.

\begin{tabular}{|c|c|c|c|c|c|c|c|}
\hline Escort RDG & $R P M_{f}$ & $R P M_{a}$ & $\left(T_{f}+T_{a}\right) / T_{\max }$ & $T_{f} / T_{a}$ & $Q_{f} / Q_{a}$ & $J_{f}$ & $\eta$ \\
\hline 2938 & 5714 & 5713 & 0.1 & 8.14 & 2.85 & 1.38 & 0.600 \\
\hline 2943 & 6094 & 6093 & 0.32 & 1.23 & 1.35 & 1.29 & 0.803 \\
\hline 2948 & 6336 & 6337 & 0.48 & 0.96 & 1.11 & 1.25 & 0.828 \\
\hline 2953 & 6475 & 6474 & 0.58 & 0.89 & 1.04 & 1.22 & 0.830 \\
\hline 2958 & 6664 & 6664 & 0.71 & 0.83 & 0.98 & 1.18 & 0.826 \\
\hline 2966 & 6943 & 6943 & 0.89 & 0.80 & 0.95 & 1.14 & 0.812 \\
\hline
\end{tabular}

to evaluate a complicated system like the ORPR with each parameter varied individually, the cost of testing and the large number of parameters combined to prevent this sort of detailed study.

\section{Unsteady Pressure Results and Discussion}

The $8 \times 6$ test section is made of stainless steel plate perforated with angled holes for boundary layer bleed during transonic operation. Needless to say, it is not an ideal acoustic environment. The redeeming aspects of this test are the high Mach number flow which pushes reflected sound waves downstream, and the excellent signal-to-noise ratio available due to the placement of the sensors in the immediate vicinity of the model.

Equation 1 can be used for calculating the frequency of interaction tones expected by an open rotor system,

$$
\text { Shaft Order Interaction Tones }=\frac{m B_{f} N_{f}+n B_{a} N_{a}}{.5\left(N_{f}+N_{a}\right)},
$$

where $m$ and $n$ are integers denoting the front and rear blade passing tone order respectively. This formula provides a good approximation to the tone order when the rotational speeds of the two rotors are nearly the same.

\subsection{Background Noise Removal}

An extensive database of "tare run" measurements was acquired. These are measurements made with the rig in the test section, but without blades installed or compressed air delivered to the turbine. Blade fillers are used to fill the gaps in the hub in the absence of rotor blades.

A typical narrowband $(12.2 \mathrm{~Hz})$ pressure spectrum from sensor 9 is presented in Figure 3 . Most of the strongest tones are at multiples of the aft rotor blade passing frequency. The plate is at location $0.78 D_{f}$ 
from the center of the rig. The plot shows both a tare run spectrum and a powered spectrum for Mach 0.78. The tones generated by the open rotor are immediately apparent, and no signal to noise problem is evident for these spectral features. The broadband signal generated by the open rotor is clearly above the tare run spectra for frequencies above $3 \mathrm{kHz}$ for the rotor speed shown.

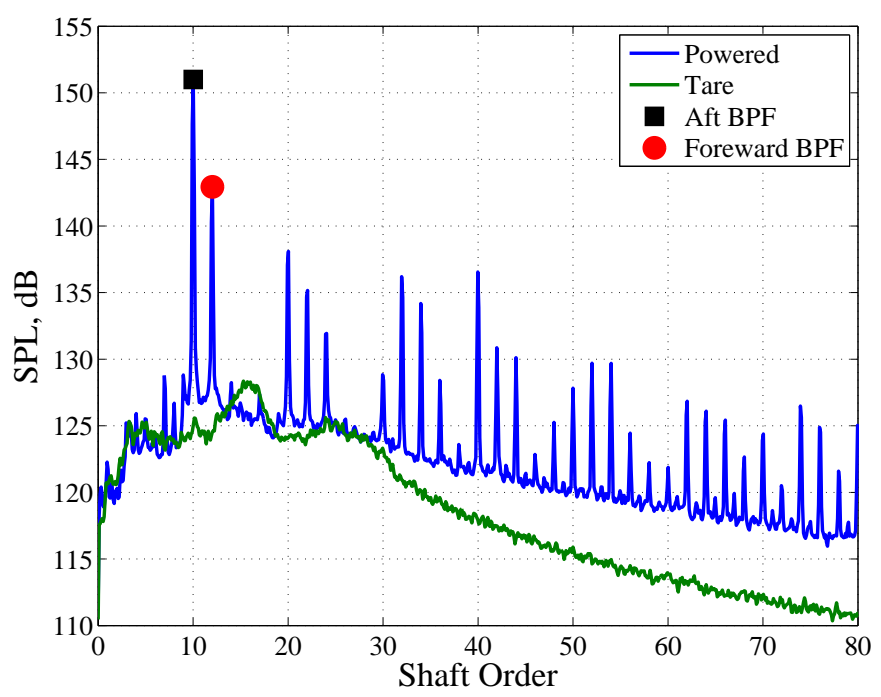

Figure 3: Nearfield unsteady pressure spectra at 90 degrees. M=0.78. Powered data at 6943 RPM.

An additional complication exists because the data were not acquired at constant emission angles or constant geometric angles, but rather at constant sideline locations. Additionally, the 17 sensors make for a somewhat sparse data set. This makes it challenging to compare measurements made a different sideline distances, since the geometric and emitted angles both change with sideline measurement location. The relationship between geometric and emission angles was calculated using,

$$
\theta_{e}=\theta_{g}-\arcsin \left(M_{0} \sin \left(\theta_{g}\right)\right),
$$

which assumes linear propagation.

\subsection{Measured Pressure Spectra}

As can be seen in Figure 3, the magnitude of the tare run spectra may be higher than that of the powered spectra for some frequencies. A background separation routine was developed, and subtraction at each frequency was carried out. If the magnitude of the appropriate tare run spectrum was less than $6 \mathrm{~dB}$ below the magnitude of the powered spectrum, the resulting value was set to not-a-number (NAN) representing an ambiguous value. These NAN values are not shown in the remaining acoustic results.

Figure 4 shows the integrated unsteady pressure generated on a sideline by the rotor at Mach 0.78 for the six conditions listed in Table 2. For these results, the tare run spectra were subtracted, a value of $0 \mathrm{~dB}$ was substituted for the NAN values and the results were integrated from 500 to $50,000 \mathrm{~Hz}$. The aft rotor is centered on $x=0$ by definition and the forward rotor is centered at $x=0.2 \mathrm{~m}$. Note that the direction of the $\mathrm{x}$-axis has been reversed for Figure 4 to correspond better with the model orientation and sensor numbering shown in Figure 2, For each value of $J_{f}$ shown in Figure 4 two peaks can be observed with a local minimum in between. For the the two highest advance ratios (lowest RPM) the forward peak is higher, while the aft peak is higher otherwise. This corresponds reasonably with the torque and thrust ratios shown in Table 2

The frequency content of each peak in the OASPL was considered in more detail. These peaks correspond to sensors 9 and 11, as described in Table 1. The narrowband sound spectra were processed using a peakfinding algorithm to identify tones which were at least $6 \mathrm{~dB}$ above the lowest magnitude level around every integer shaft order. If a tone was found, the spectral energy in that tone was summed. The tone content was 
Table 3: Decibel levels of blade rate tones for forward and aft rotor.

\begin{tabular}{|l|l|l|l|l|l|l|}
\hline Advance Ratio $J_{f}$ & 1.38 & 1.29 & 1.25 & 1.22 & 1.18 & 1.14 \\
\hline Sensor 11, SO = 12 & 145.8 & 151.3 & 156.1 & 157.5 & 159.2 & 162.1 \\
\hline Sensor 9, SO = 10 & 143.0 & 150.8 & 157.5 & 159.2 & 159.7 & 162.9 \\
\hline
\end{tabular}

usually spread over three or four frequency bins, due to slight drifting of the rotor speed. If a peak was not found, an average broadband level was calculated. If only values of NAN were found, indicating levels below the tare run level, NAN was returned. This data was used to create the bar charts of Figure 5 and Figure 6 , which denote the $\mathrm{dB}$ level (ref $20 \mu \mathrm{Pa}$ ) of the RMS pressure at integer shaft orders. This processing method was found to be useful for quantifying both tone and broadband levels in one plot, while still accounting for NAN values in the spectra.

Aft rotor tones dominate the spectra measured by sensor 9, as shown in Figure 15, while interaction tones $\left(m B_{f}+n B_{a}\right)$ are a much smaller contribution. The second aft tone harmonic was an average of $6.8 \mathrm{~dB}$ below the first for the six conditions considered, while the third tone dropped another $4.7 \mathrm{~dB}$ on average. The forward rotor tones were at least $9.1 \mathrm{~dB}$ below the aft tone of the same order, for the first three harmonics.

Forward rotor tones dominate the spectra measured by sensor 11, as shown in Figure 6. Interaction tones again were not found to be a significant contribution. The forward tone harmonics were found to decrease differently than the aft tones, as the second forward tone harmonic was an average of $4.6 \mathrm{~dB}$ below the first and the third tone dropped another $7.5 \mathrm{~dB}$ on average. The aft rotor tones were a minimum of $5.5 \mathrm{~dB}$ below the forward tone of the same order, for the first three harmonics.

The directivity of the first forward and aft blade passing tones were also examined. These tones were chosen for closer examination because they are among the strongest and because these lower frequencies have larger wavelengths and so are better resolved by the sparse spatial measurement. A quick consideration of the emitted angles revealed the need to consider the forward and aft tones as being emitted from two different spatial locations. The close proximity of the measurement sideline makes this significant. For an observer much further away, the emitted angles would tend towards the same values for each rotor. In Figure 7. the emitted angles for the forward and aft rotor tones are plotted with respect to the center of the forward and aft rotors, respectively. On these figures, the center sensor corresponds to the data presented in Figure 5 and is called out with a large marker. This geometry definition causes the radiation patters to collapse quite nicely, as shown in Figure 7 (a), (c) and (e). No magnitude correction was made for these results, as the measurements were clearly made in the acoustic near-field and using free-field distance corrections would not be meaningful. The corresponding mean squared coherence is shown in (b), (d) and (f) of Figure 7for the same three values of advance ratio. The coherence was calculated by using the sensor closest to 40 degrees emission angle as the reference, with the appropriate origin for each rotor tone as previously described. This emission angle generally measured the highest levels for these two tones. At the highest RPM (lowest advance ratio for constant Mach number) conditions, these tones are coherent over a very wide angle. Abrupt changes in the coherence are likely due to reflections of pressure waves between the aluminum plate and the ORPR.

The peak levels for the two blade rate tones were found to be remarkably close in magnitude, although measured by different sensors. These values are given in Table 3. Aside from $J_{f}=1.38$, which corresponds to a thrust ratio of $T_{f} / T_{a}=8.14$, these tone levels are within $1.7 \mathrm{~dB}$. The diminutive contribution of the interaction tones is likely due to the smaller diameter of the aft rotor, which is designed to reduce the interaction of the aft rotor with the blade tip vortices from the front rotor. This effect was noted by Dittmar and Stang [2] and by Woodward and Gordon[11].

\section{Conclusions}

An extensive test campaign considering a model scale open rotor at cruise conditions has been completed, and a brief overview of the unsteady pressure results has been provided. The OASPL on a $0.78 D_{f}$ sideline exceeds $175 \mathrm{~dB}$, with the blade rate tone and harmonics responsible for the majority of this signal. These pressure spectra have high coherence (MSC > .9) over emitted angles between 25 and 75 degrees. 


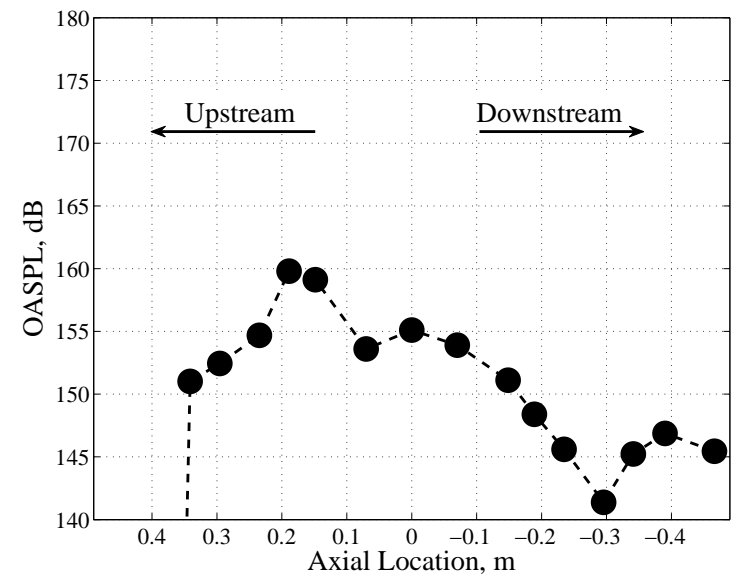

(a) $J_{f}=1.38$

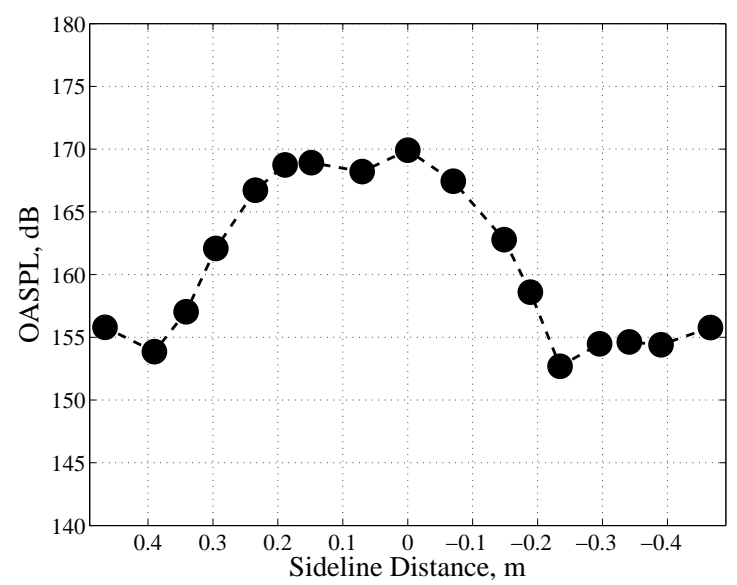

(c) $J_{f}=1.25$

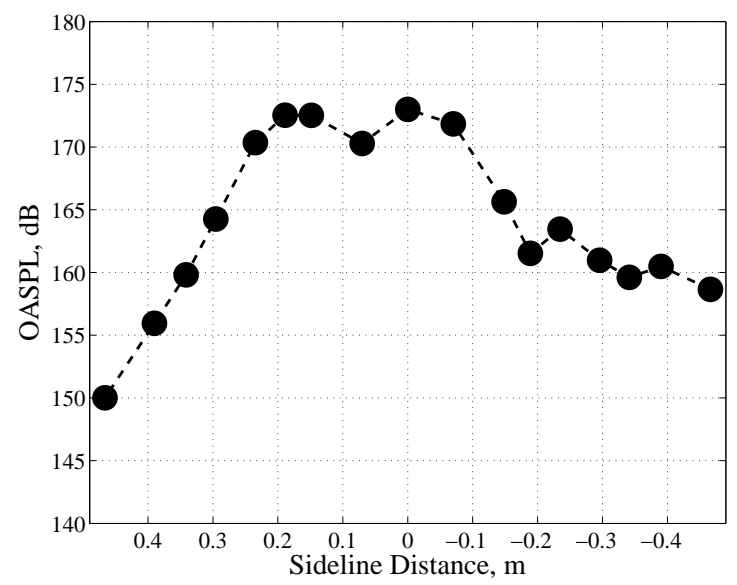

(e) $J_{f}=1.18$

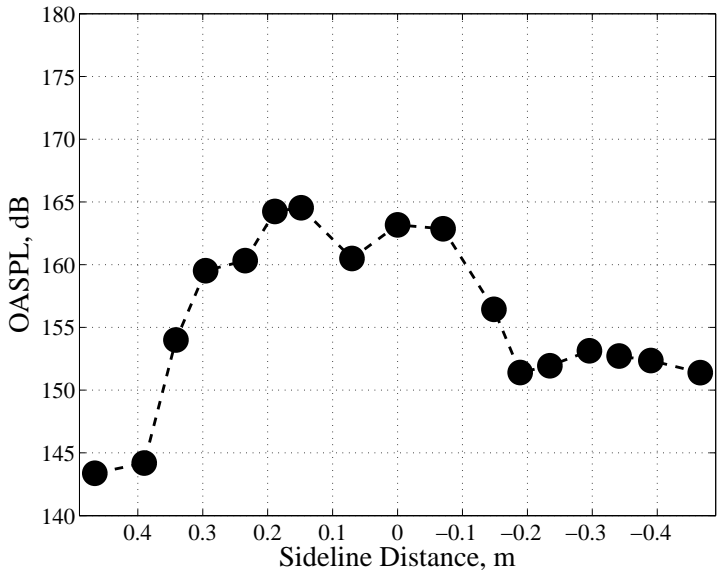

(b) $J_{f}=1.29$

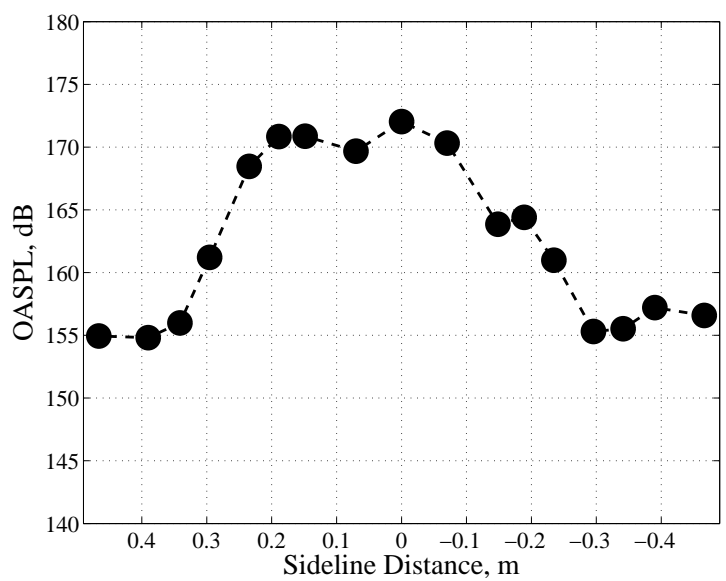

(d) $J_{f}=1.22$

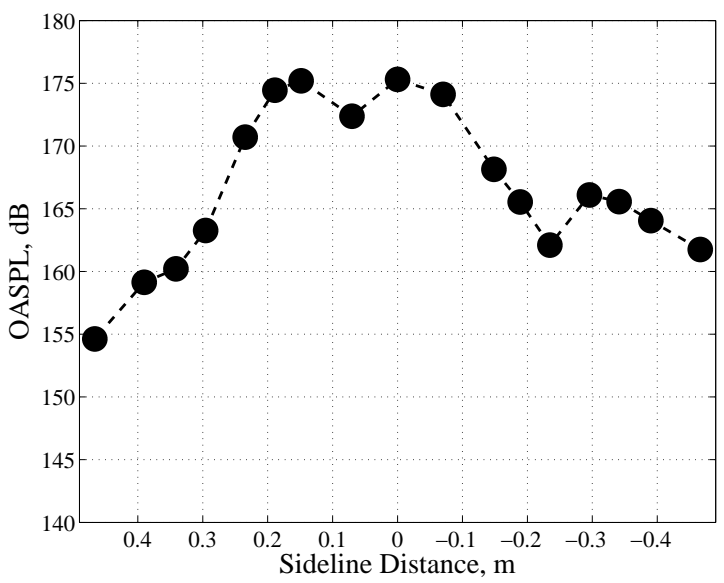

(f) $J_{f}=1.14$

Figure 4: OASPL levels along the measurement sideline for each sensor at the six conditions shown in Table 2. Note that the direction of the $\mathrm{x}$-axis has been reversed to correspond better with the model orientation and sensor numbering shown in Figure 2 


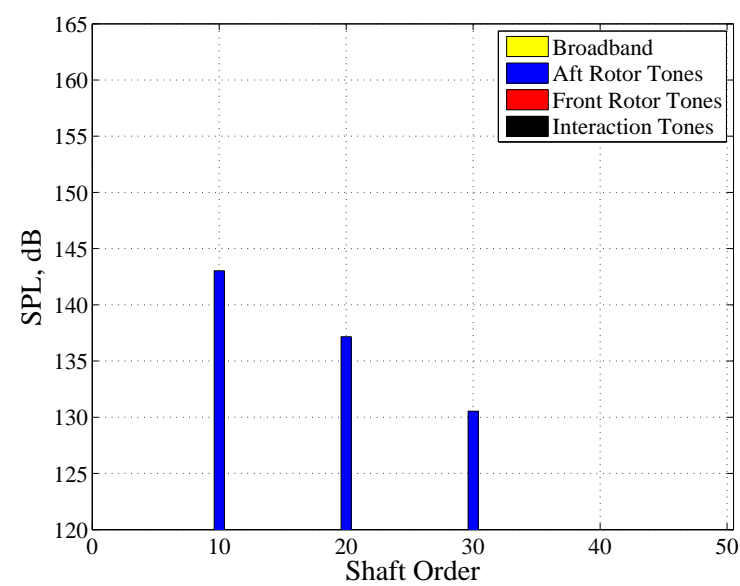

(a) $J_{f}=1.38$

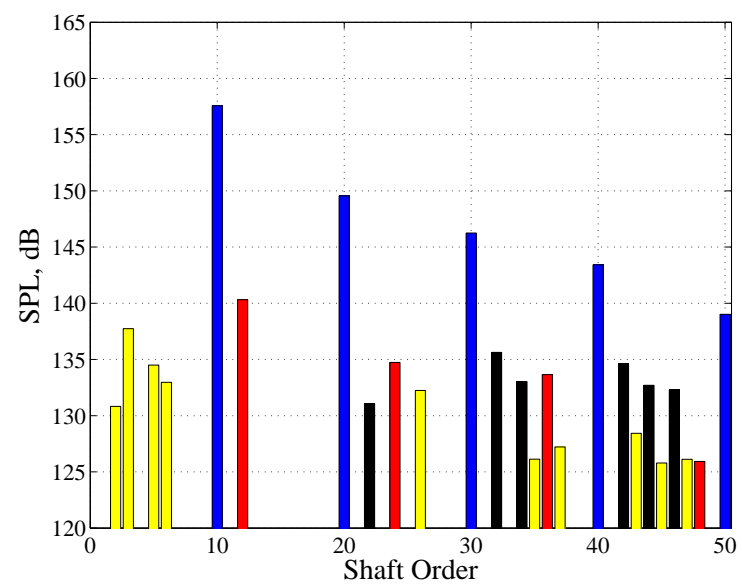

(c) $J_{f}=1.25$

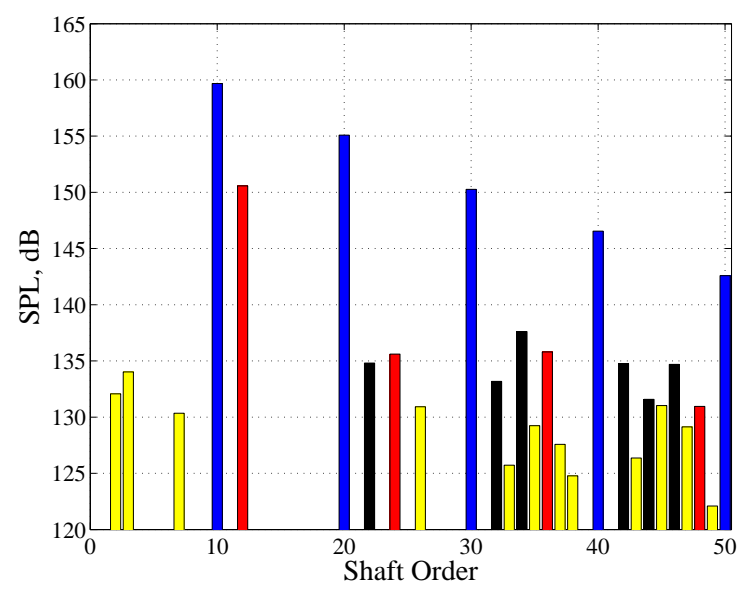

(e) $J_{f}=1.18$

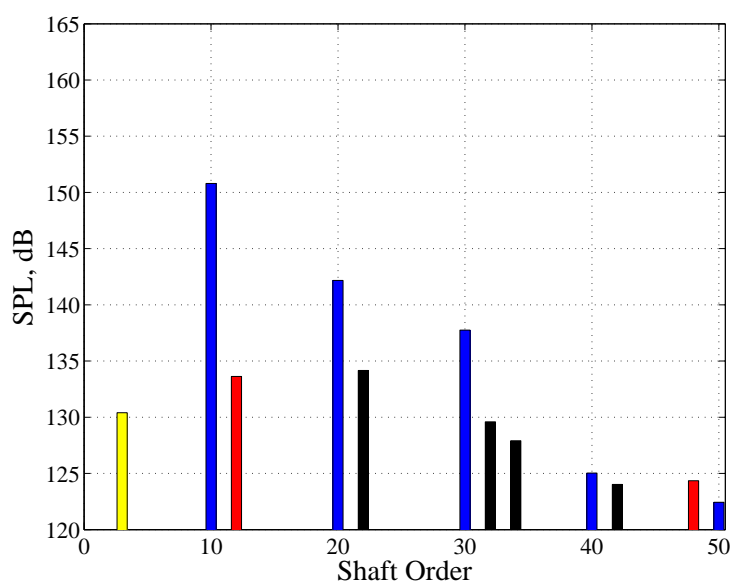

(b) $J_{f}=1.29$

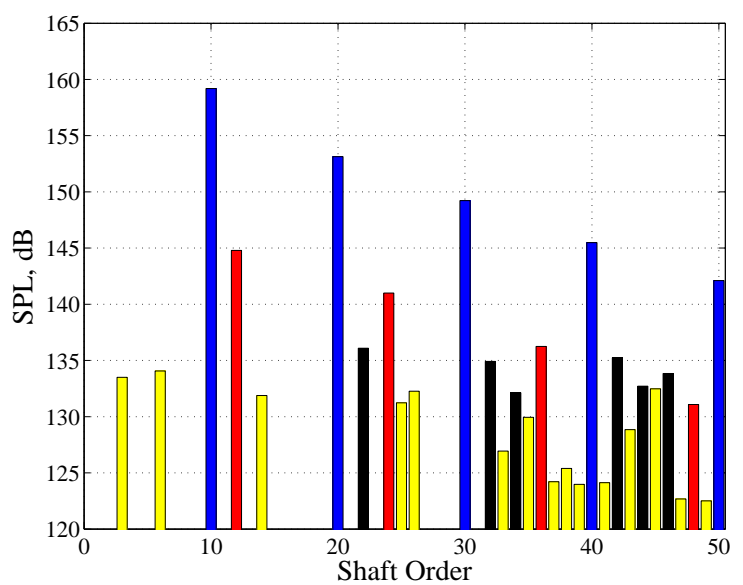

(d) $J_{f}=1.22$

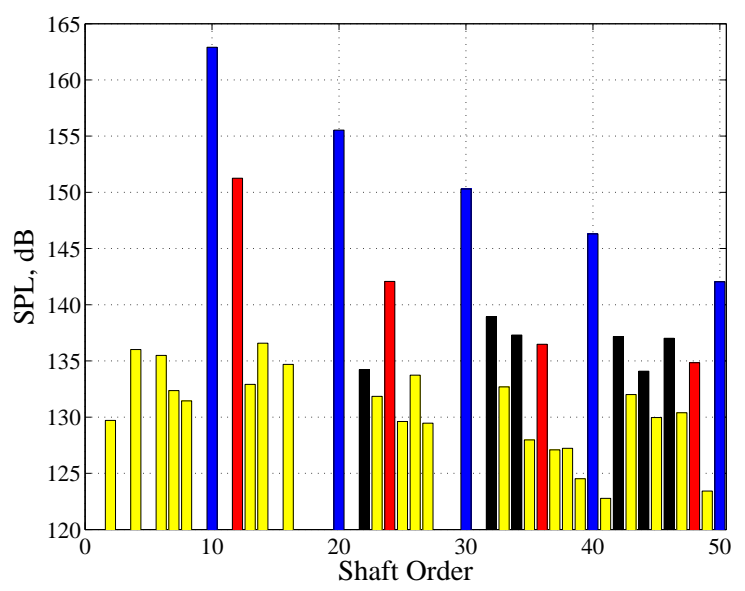

(f) $J_{f}=1.14$

Figure 5: Spectral content of unsteady pressure measured by sensor number 9 at various advance ratios, Mach 0.78. $\theta_{g}=90$ degrees. $\theta_{e}=39$ degrees. 


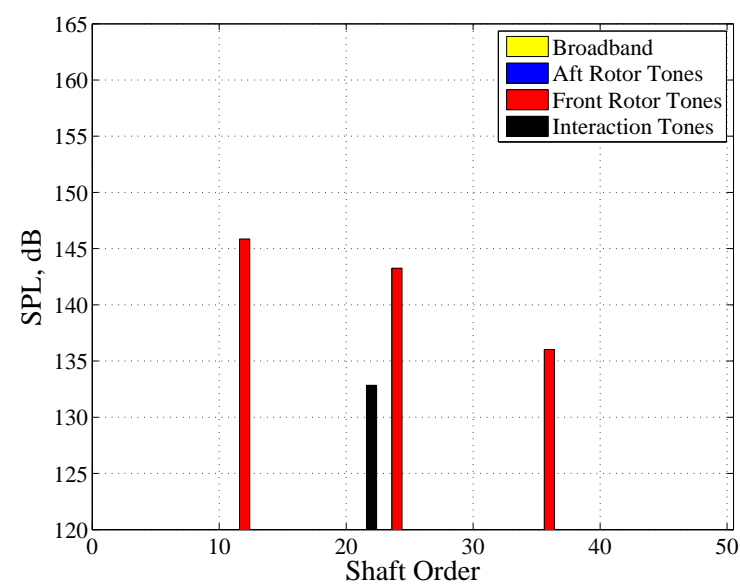

(a) $J_{f}=1.38$

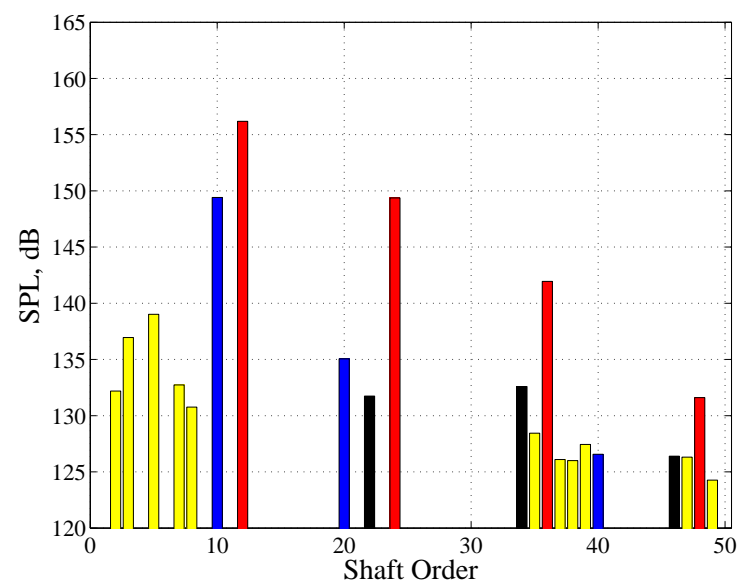

(c) $J_{f}=1.25$

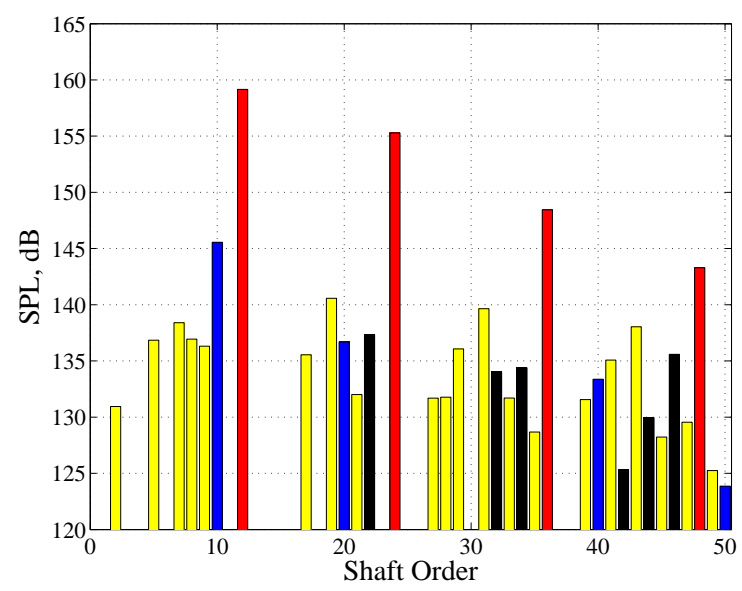

(e) $J_{f}=1.18$

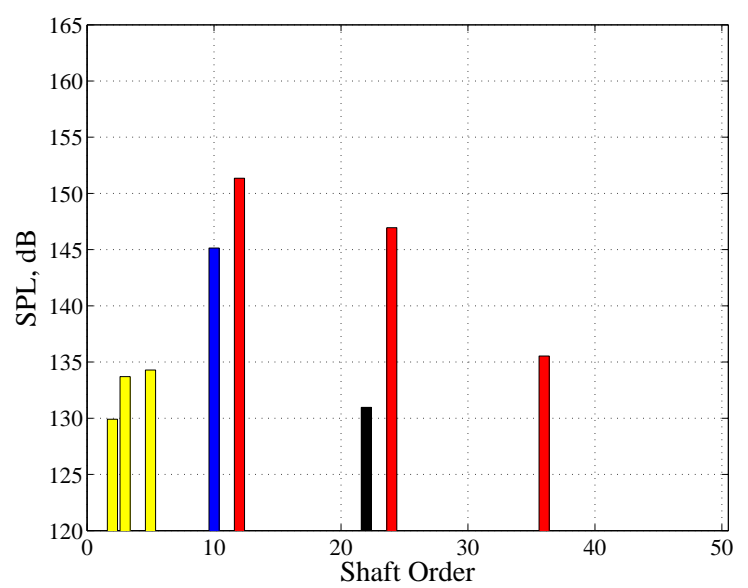

(b) $J_{f}=1.29$

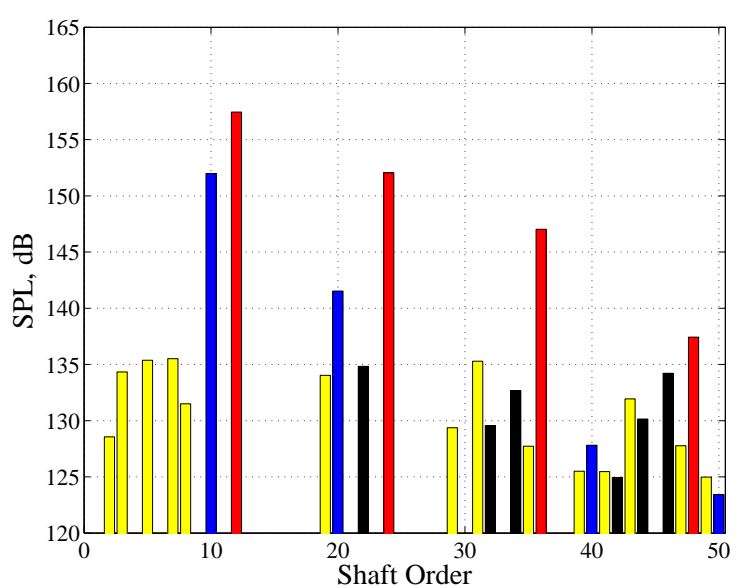

(d) $J_{f}=1.22$

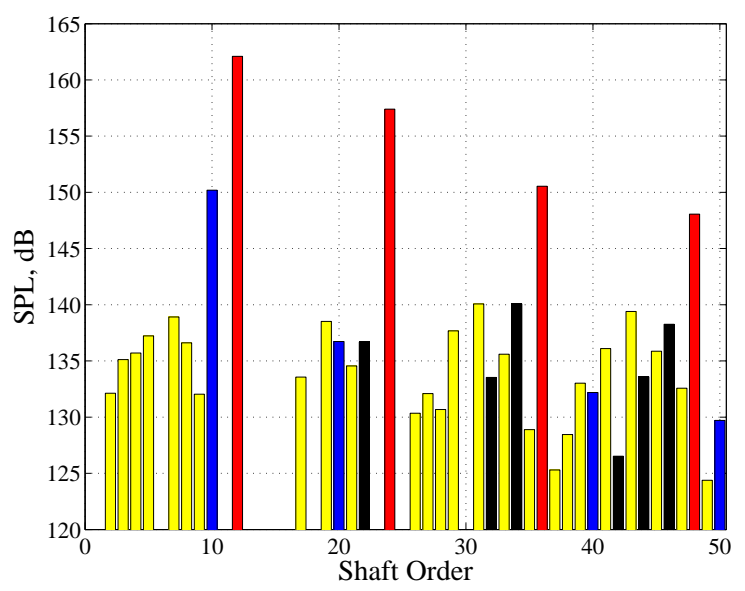

(f) $J_{f}=1.14$

Figure 6: Spectral content of unsteady pressure measured by sensor number 11 at various advance ratios, Mach 0.78. $\theta_{e}=74$ degrees. $\theta_{e}=25$ degrees. 


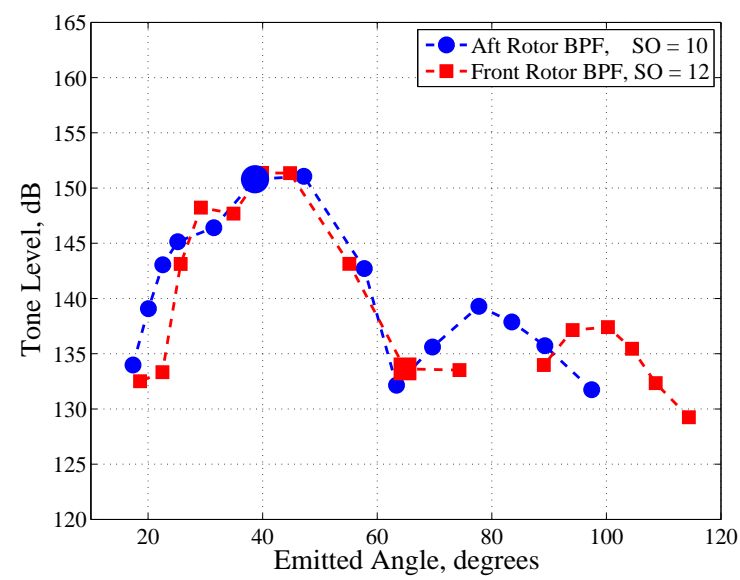

(a) $J_{f}=1.29$

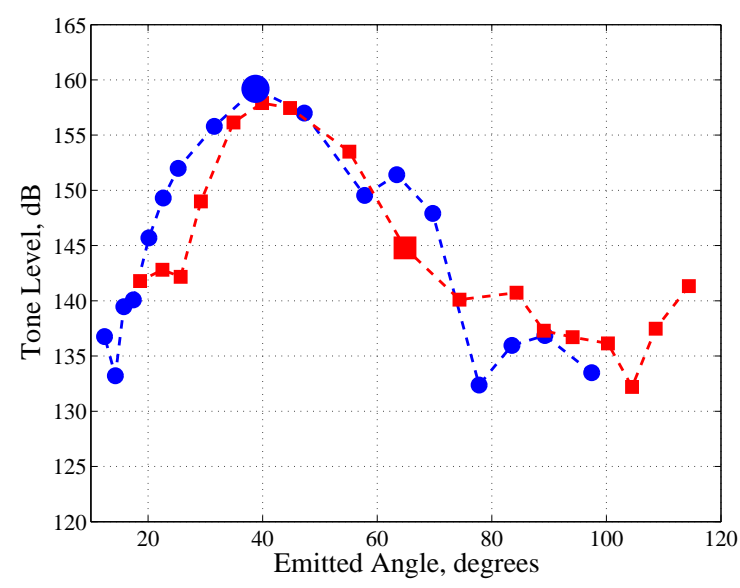

(c) $J_{f}=1.22$

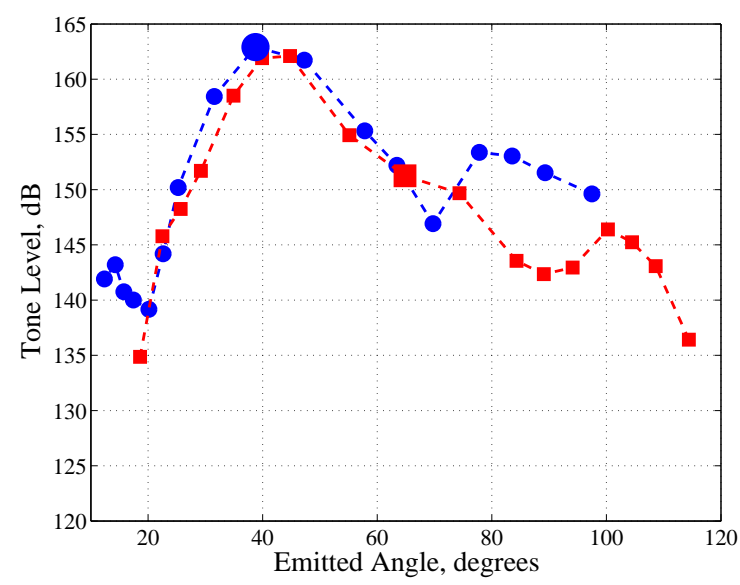

(e) $J_{f}=1.14$

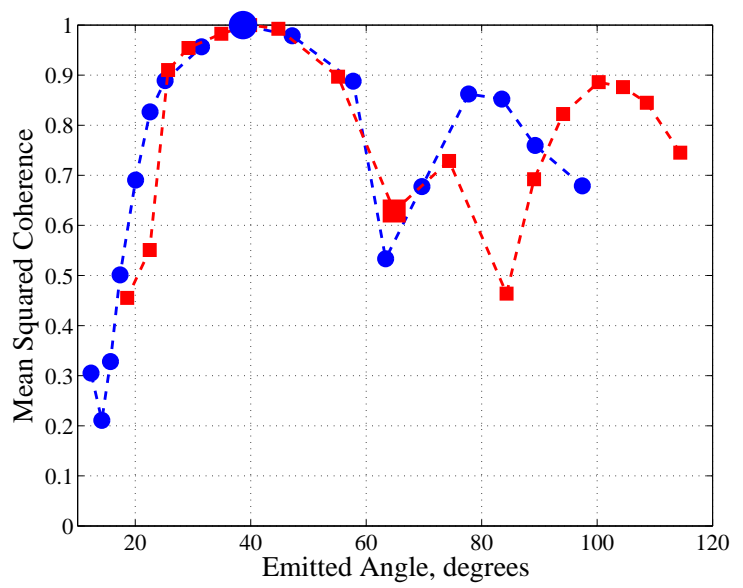

(b) $J_{f}=1.29$

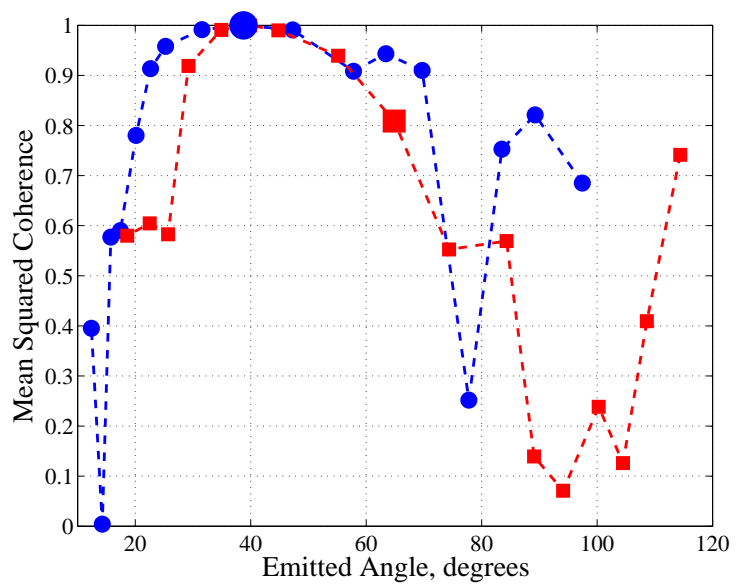

(d) $J_{f}=1.22$

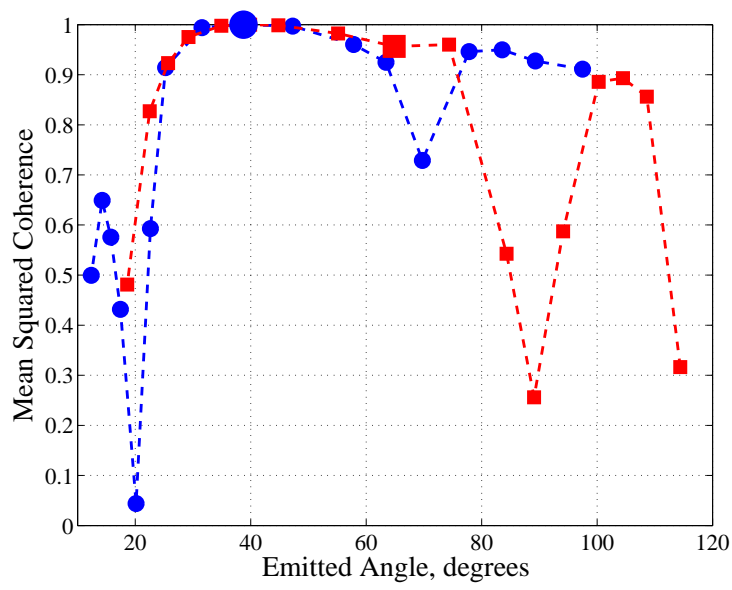

(f) $J_{f}=1.14$

Figure 7: Directivity and coherence of aft and forward blade passing frequency tones. Emission angle has been calculated from the center of the respective rotor. Large symbol indicates center sensor. $\mathrm{M}=0.78$. 


\section{References}

[1] Dittmar, J. H., "Cruise Noise of Counterrotation Propeller at Angle of Attack in Wind Tunnel," NASA/TM-88869, October 1986.

[2] Dittmar, J. H. and Stang, D. B., "Noise Reduction for Model Counterrotation Porpeller at Cruise by Reducing Aft-Propeller Diameter," NASA TM-88936, May 1987.

[3] Dittmar, J. H., Gordon, E. B., and Jeracki, R. J., "The Effect of Front-to-Rear Propeller Spacing on the Interaction Noise at Cruise Conditions of a Model Counterrotation Propeller Having a Reduced Diameter Aft Propeller," NASA TM-101329, October 1988.

[4] Whitfield, C. E., Mani, R., and Gliebe, P. R., "High Speed Turboprop Aeroacoustic Study (Counterrotation) Volume I - Model Development," NASA CR-185241, July 1990.

[5] Woodward, R. P., Loeffler, I. J., and Dittmar, J. H., "Measured Far-Field Flight Noise of a Counterrotation Turboprop at Cruise Conditions," NASA/TM-101383, January 1989.

[6] Elliott, D. M., "Initial Investigation of the Acoustics of a Counter Rotating Open Rotor Model With Historical Baseline Blades in a Low Speed Wind Tunnel. AIAA-2011-2760," 17th AIAA/CEAS Aeroacoustics Conference,, Portland, Oregon, USA, 5-8 June 2011.

[7] Stephens, D. B. and Envia, E., "Acoustic Shielding for a Model Scale Counter-rotation Open Rotor. AIAA-2011-2940," 17th AIAA/CEAS Aeroacoustics Conference,, Portland, Oregon, USA, 5-8 June 2011.

[8] Berton, J. J., "Empennage Noise Shielding Benefits for an Open Rotor Transport. AIAA-2011-2764," 17th AIAA/CEAS Aeroacoustics Conference,, Portland, Oregon, USA, 5-8 June 2011.

[9] Soeder, R. H., "NASA Lewis 8- by 6-Foot Low-Speed Wind Tunnel User Maunal," NASA/TM 105771, February 1993.

[10] Hughes, C. E. and Gazzaniga, J. A., "Summary of Low-Speed Wind Tunnel Results of Several HighSpeed Counterrotation Propeller Configurations. AIAA-1988-3149," AIAA/ASME/SAE/ASEE 24th Joint Propulsion Conference,, Boston, Massachusetts, USA, 11-13 July 1988.

[11] Woodward, R. P. and Gordon, E. B., "Noise of a Model Counterrotation Propeller With Reduced Aft Rotor Diameter at Simulated Takeoff/Approach Conditions. AIAA-1988-0263," AIAA 26th Aerospace Sciences Meeting,, Reno, Nevada, USA, 11-14 January 1988. 


\begin{tabular}{|c|c|c|c|c|c|}
\hline \multicolumn{5}{|c|}{ REPORT DOCUMENTATION PAGE } & $\begin{array}{l}\text { Form Approved } \\
\text { OMB No. 0704-0188 }\end{array}$ \\
\hline \multicolumn{6}{|c|}{ 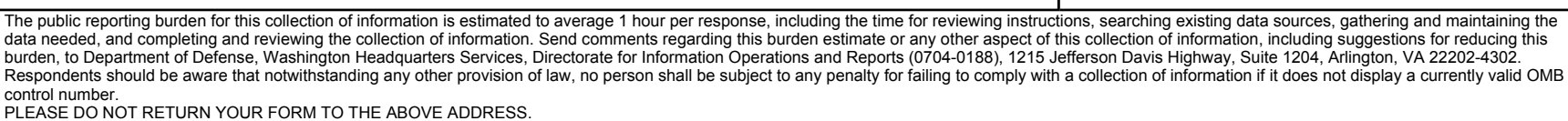 } \\
\hline \multicolumn{2}{|c|}{$\begin{array}{l}\text { 1. REPORT DATE (DD-MM-YYYY) } \\
01-09-2012\end{array}$} & \multicolumn{3}{|c|}{$\begin{array}{l}\text { 2. REPORT TYPE } \\
\text { Technical Memorandum }\end{array}$} & 3. DATES COVERED (From - To) \\
\hline \multirow{3}{*}{\multicolumn{5}{|c|}{$\begin{array}{l}\text { 4. TITLE AND SUBTITLE } \\
\text { Nearfield Unsteady Pressures at Cruise Mach Numbers for a Model Scale Counter-Rotation } \\
\text { Open Rotor }\end{array}$}} & 5a. CONTRACT NUMBER \\
\hline & & & & & 5b. GRANT NUMBER \\
\hline & & & & & 5c. PROGRAM ELEMENT NUMBER \\
\hline \multirow{3}{*}{\multicolumn{5}{|c|}{$\begin{array}{l}\text { 6. AUTHOR(S) } \\
\text { Stephens, David, B. }\end{array}$}} & 5d. PROJECT NUMBER \\
\hline & & & & & 5e. TASK NUMBER \\
\hline & & & & & $\begin{array}{l}\text { 5f. WORK UNIT NUMBER } \\
\text { WBS 699959.02.09.03.05 }\end{array}$ \\
\hline \multicolumn{5}{|c|}{$\begin{array}{l}\text { 7. PERFORMING ORGANIZATION NAME(S) AND ADDRESS(ES) } \\
\text { National Aeronautics and Space Administration } \\
\text { John H. Glenn Research Center at Lewis Field } \\
\text { Cleveland, Ohio 44135-3191 }\end{array}$} & $\begin{array}{l}\text { 8. PERFORMING ORGANIZATION } \\
\text { REPORT NUMBER } \\
\text { E- } 18347\end{array}$ \\
\hline \multirow{2}{*}{\multicolumn{5}{|c|}{$\begin{array}{l}\text { 9. SPONSORING/MONITORING AGENCY NAME(S) AND ADDRESS(ES) } \\
\text { National Aeronautics and Space Administration } \\
\text { Washington, DC 20546-0001 }\end{array}$}} & $\begin{array}{l}\text { 10. SPONSORING/MONITOR'S } \\
\text { ACRONYM(S) } \\
\text { NASA }\end{array}$ \\
\hline & & & & & $\begin{array}{l}\text { 11. SPONSORING/MONITORING } \\
\text { REPORT NUMBER } \\
\text { NASA/TM-2012-217672 }\end{array}$ \\
\hline \multicolumn{6}{|c|}{$\begin{array}{l}\text { 12. DISTRIBUTION/AVAILABILITY STATEMENT } \\
\text { Unclassified-Unlimited } \\
\text { Subject Categories: } 71 \text { and } 01 \\
\text { Available electronically at http://www.sti.nasa.gov } \\
\text { This publication is available from the NASA Center for AeroSpace Information, 443-757-5802 }\end{array}$} \\
\hline \multicolumn{6}{|c|}{ 13. SUPPLEMENTARY NOTES } \\
\hline \multirow{2}{*}{\multicolumn{6}{|c|}{$\begin{array}{l}\text { 14. ABSTRACT } \\
\text { An open rotor experiment was conducted at cruise Mach numbers and the unsteady pressure in the nearfield was measured. The system } \\
\text { included extensive performance measurements, which can help provide insight into the noise generating mechanisms in the absence of flow } \\
\text { measurements. A set of data acquired at a constant blade pitch angle but various rotor speeds was examined. The tone levels generated by } \\
\text { the front and rear rotor were found to be nearly equal when the thrust was evenly balanced between rotors. } \\
\text { 15. SUBJECT TERMS } \\
\text { Counter rotation; Rotors; Wind tunnel tests }\end{array}$}} \\
\hline & & & & & \\
\hline \multicolumn{3}{|c|}{ 16. SECURITY CLASSIFICATION OF: } & $\begin{array}{l}\text { 17. LIMITATION OF } \\
\text { ABSTRACT }\end{array}$ & $\begin{array}{l}\text { 18. NUMBER } \\
\text { OF }\end{array}$ & $\begin{array}{l}\text { 19a. NAME OF RESPONSIBLE PERSON } \\
\text { STI Help Desk (email:help@sti.nasa.gov) }\end{array}$ \\
\hline $\begin{array}{l}\text { a. REPORT } \\
\mathrm{U}\end{array}$ & $\begin{array}{l}\text { b. ABSTRACT } \\
U\end{array}$ & $\begin{array}{l}\text { C. THIS } \\
\text { PAGE } \\
\text { U }\end{array}$ & UU & $\begin{array}{l}\text { PAGES } \\
18\end{array}$ & $\begin{array}{l}\text { 19b. TELEPHONE NUMBER (include area code) } \\
443-757-5802\end{array}$ \\
\hline
\end{tabular}



